\title{
Author Correction: Aberrant activation of non-coding RNA targets of transcriptional elongation complexes contributes to TDP-43 toxicity
}

Chia-Yu Chung1,2, Amit Berson ${ }^{1}$, Jason R. Kennerdell ${ }^{1}$, Ashley Sartoris ${ }^{1}$, Travis Unger ${ }^{3}$, Sílvia Porta ${ }^{4}$, Hyung-Jun Kim ${ }^{1,6}$, Edwin R. Smith ${ }^{5}$, Ali Shilatifard (10 ${ }^{5}$, Vivianna Van Deerlin ${ }^{4}$, Virginia M.-Y. Lee ${ }^{4}$, Alice Chen-Plotkin ${ }^{2,3}$ \& Nancy M. Bonini (iD ${ }^{1}$

Correction to: Nature Communications; https://doi.org/10.1038/s41467-018-06543-0; published online 23 Oct 2018.

The original version of this Article contained an error in the author affiliations. The affiliation of Alice Chen-Plotkin with the Department of Neurology, Perelman School of Medicine, Philadelphia, PA, 19104 USA was inadvertently omitted. This has now been corrected in both the PDF and HTML versions of the Article.

Published online: 29 January 2019

\footnotetext{
(c) (i) Open Access This article is licensed under a Creative Commons Attribution 4.0 International License, which permits use, sharing, adaptation, distribution and reproduction in any medium or format, as long as you give appropriate credit to the original author(s) and the source, provide a link to the Creative Commons license, and indicate if changes were made. The images or other third party material in this article are included in the article's Creative Commons license, unless indicated otherwise in a credit line to the material. If material is not included in the article's Creative Commons license and your intended use is not permitted by statutory regulation or exceeds the permitted use, you will need to obtain permission directly from the copyright holder. To view a copy of this license, visit http://creativecommons.org/licenses/by/4.0/.
}

() The Author(s) 2019

\footnotetext{
${ }^{1}$ Department of Biology, University of Pennsylvania, Philadelphia, PA 19104, USA. ${ }^{2}$ Cell and Molecular Biology Graduate Group, Perelman School of Medicine, Philadelphia, PA 19104, USA. ${ }^{3}$ Department of Neurology, Perelman School of Medicine, Philadelphia, PA 19104, USA. ${ }^{4}$ Department of Pathology and Laboratory Medicine, Perelman School of Medicine, Philadelphia, PA 19104, USA. ${ }^{5}$ Department of Biochemistry and Molecular Genetics, Feinberg School of Medicine, Northwestern University, Chicago, IL 60611, USA. ${ }^{6}$ Present address: Department of Neural Development and Disease, Korea Brain Research Institute (KBRI), Daegu 41068, South Korea Correspondence and requests for materials should be addressed to N.M.B. (email: nbonini@sas.upenn.edu)
} 